\title{
Morphometric Analysis of the Palpebral Fissure and Canthal Distance in Serbian Young Adults
}

\author{
Análisis Morfométrico de la Fisura Palpebral y la Distancia Cantal en Adultos Jóvenes Serbios
}

\author{
Knezi Nikola ${ }^{1}$; Isaretovic Vladimir ${ }^{2}$; Adjic Ivan ${ }^{3}$; Babic Nikola ${ }^{4}$ Maric Dusica ${ }^{1}$ \& Stojsic Dzunja Ljubica ${ }^{1}$
}

KNEZI, N.; ISARETOVIC, V; ADJIC, I.; BABIC, N.; MARIC, D. \& STOJSIC-DZUNJA, L. Morphometric analysis of the palpebral fissure and canthal distance in Serbian young adults. Int. J. Morphol., 38(5):1381-1385, 2020.

SUMMARY: Frontaly and anteriorly the orbit is closed by a skin-muscular closure of eyelids. The eyelids limit the palpebral fissure, which is subject to geographical, racial, and age variations. As a part of the face, eyelids and palpebral fissure play a very important role in the attractiveness of the individual, but al so in the diagnosis of certain local and systemic pathological processes. The aim of the study was to perform a morphometric analysis of the palpebral fissure in a young population without pathological conditions and syndromes. The study was conducted on 90 subjects (45 male and 45 female) aged $19.28 \pm 0.69$ years. Subjects were photographed with a Nikon D3400 camera, and the morphometric parameters were measured with the ImageJ $1.48 \mathrm{v}$ software. Statistical analysis of the data was performed in Windows Excel. The measurements in the study were the distance between the mid-points of both pupils, distance between both external canthi, distance between both internal canthi, palpebral fissure width and palpebral fissure height at three points. The average height of the palpebral fissure to the right is $9.35 \pm 1.55 \mathrm{~mm}$ and to the left is $9.41 \pm 1.56 \mathrm{~mm}$. The average width of the palpebral fissure on the right is $27.05 \pm 1.71 \mathrm{~mm}$ and on the left is $27.18 \pm 1.68 \mathrm{~mm}$. It was found that there was some difference in the measured parameters, however, this difference was not statistically significant.

KEY WORDS: Morphometry; Palpebral fissure; Canthal distance.

\section{INTRODUCTION}

The palpebral fissure is a natural opening of the face which is limited with the free edges of upper and lower eyelids and the angles which correspond to the junction of both eyelids, which we call inner or medial canthus and outer or lateral canthus (Preechawai, 2011; Standring, 2016). This fissure is positioned in a way that the longer axis is in horizontal position and the shorter axis is in vertical position (Hall et al., 2007). Yu et al. (2019) describe that in many races woman have rounder eyes, while men have silghtly wider and significantly vertically narrower or almond shaped eyes.

The morphometric characteristics of the palpebral fissure and canthal distance vary according to rase, ethnicity, age and sex, which is confirmed by many published and normative values which may serve as a reference in the index population (Vasanthakumar et al., 2012; Yu et al.). Also, an important factor in the morphometric analysis of the palpebral fissure are certain differences between the right and left sides of the human face, which are often present. Asymmetry is present when certain mean values are exceded (Song et al., 2007).

This region is located in the upper part of the face, where it plays a crucial role in the perception of facial youthfulness and health. Its position may be altered in facial deformities (Jaja et al., 2011; Vasanthakumar et al., 2013). Knowledge of normal dimensions and the existence of asymmetry of the palpebral fissure is of value in several clinical specialities including ophtalmology, reconstructive surgery and traumatology, where it plays a part in the management, planning and outcomes. Causes of the symmetrical changes of dimensions are metabolic diseases or syndromes while cause of asymmetry include trauma, facial muscle palsy or tumors in the orbiral cavity (Vezel et al., 2000; Miot et al., 2009).

\footnotetext{
${ }^{1}$ University of Novi Sad, Faculty of Medicine, Department of Anatomy, Serbia.

${ }^{2}$ University of Belgrade, Faculty of Medicine, Serbia.

${ }^{3}$ Oncology Institute of Vojvodina, Sremska Kamenica, Serbia.

${ }^{4}$ University of Novi Sad, Faculty of Medicine, Department of Ophthalmology, Serbia.
} 
The aim of the present study was to analyze the palpebral fissure dimensions and determine the mean values in a population of Serbian young adults without pathological conditions and syndromes.

\section{MATERIAL AND METHOD}

The prospective study consists of 90 healthy students (45 females and 45 males) aged 19.28 \pm 0.69 ( $19.16 \pm 0.63$ female and $19.40 \pm 0.71$ male) years. Subjects with observable defects or congenital anomalies were excluded from the study, but individuals with refractive error from $+4 \mathrm{D}$ to $-6 \mathrm{D}$ were included.

The subjects were photographed with a Nikon D3400 with indirect lighting from a distance of $45 \mathrm{~cm}$ at eye-height, by the same photographer and in a well-lit room. Image size was 1500 pixels (height) by 1125 pixels (width) sorted in JPEG format. A software program for morphometric measurement, ImageJ $1.48 \mathrm{v}$, was used for

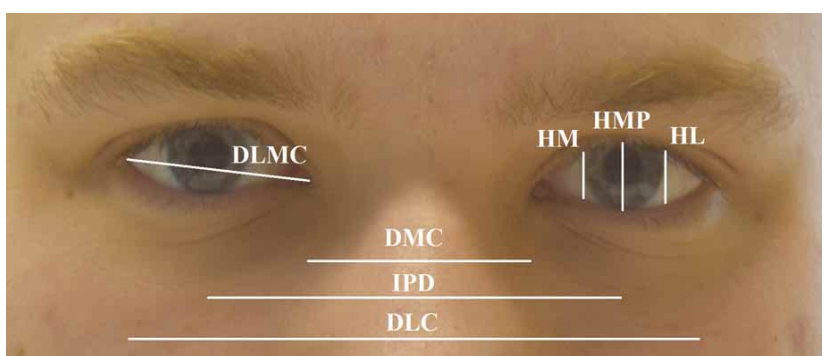

Fig. 1. Morphometric parameters of the palpebral fissure. Interpupillary distance (IPD), distance between both medial canthi (DMC), distance between lateral canthi (DLC), distance between medial and lateral canthi (DLMC), distance between upper and the lower eyelid margin in the mid-pupillary plane (HMP), distance between upper and the lower eyelid margin tangential to the medial of iris' edge (HM), distance between upper and the lower eyelid margin tangential to the lateral of iris' edge (HL). images analysis. Morphometric analysis included (Fig. 1): Interpupillary distance (IPD), distance between both medial canthi (DMC), distance between lateral canthi (DLC), distance between medial and lateral canthi (DLMC), distance between upper and the lower eyelid margin in the mid-pupillary plane (HMP), distance between upper and the lower eyelid margin tangential to the medial of iris' edge (HM), distance between upper and the lower eyelid margin tangential to the lateral of iris' edge (HL). In the present study canthal index (DMC/DLCx100) and palpebral fissure height-length ratio (HMP/DLMCx100) also was computed.

The Windows Excel program was used for statistical analysis of measurements (mean and SD). Comparison of average values for the groups was conducted using Student t-test, and statistical significance determined at $\mathrm{p}<0.05$.

Approval from the Institutional Ethics committee was given for the study.

\section{RESULTS}

The morphometric measurements and p-values in a population of Serbian young adults are presented in Tables I-III.

Table I. Results of the periocular measured parameters in examined population (in $\mathrm{mm}$ ).

\begin{tabular}{lccc}
\hline & All & Male & Female \\
\hline IPD & $60.48 \pm 3.39$ & $60.28 \pm 3.32$ & $60.77 \pm 3.58$ \\
DMC & $31.23 \pm 2.82$ & $31.28 \pm 2.95$ & $31.14 \pm 2.67$ \\
DLC & $84.97 \pm 4.44$ & $85.10 \pm 4.48$ & $84.76 \pm 4.99$ \\
Canthal index & $36.74 \pm 2.50$ & $36.77 \pm 2.57$ & $36.69 \pm 2.44$ \\
\hline
\end{tabular}

IPD - interpupillary distance; DMC - distance between both medial canthi; DLC - distance between lateral canthi.

Table II. Results of the intaocular measured parameters in examined population (in $\mathrm{mm}$ ).

\begin{tabular}{|c|c|c|c|c|c|c|}
\hline & \multicolumn{2}{|c|}{ All } & \multicolumn{4}{|c|}{ Sex } \\
\hline & Right side & Left side & $\mathrm{p}$ & Male & Female & $\mathrm{p}$ \\
\hline HMP & $9.35 \pm 1.55$ & $9.41 \pm 1.56$ & 0.15 & $9.43 \pm 1.41$ & $9.14 \pm 1.59$ & 0.16 \\
\hline HM & $7.40 \pm 1.61$ & $7.12 \pm 1.35$ & 0.01 & $7.34 \pm 1.30$ & $7.02 \pm 1.62$ & 0.13 \\
\hline HL & $7.68 \pm 1.68$ & $7.87 \pm 1.82$ & 0.08 & $7.74 \pm 1.63$ & $7.51 \pm 1.72$ & 0.24 \\
\hline DLMC & $27.05 \pm 1.71$ & $27.18 \pm 1.68$ & 0.19 & $27.19 \pm 1.75$ & $26.90 \pm 1.54$ & 0.18 \\
\hline Height-length ratio & $34.78 \pm 5.08$ & $34.76 \pm 4.86$ & 0.87 & $36.01 \pm 4,87$ & $33.82 \pm 5.13$ & 0,02 \\
\hline
\end{tabular}

HMP - distance between upper and the lower eyelid margin in the mid-pupillary plane; HM -distance between upper and the lower eyelid margin tangential to the medial of iris' edge; HL - distance between upper and the lower eyelid margin tangential to the lateral of iris' edge; DLMC - distance between medial and lateral canthi. 
Table III. Results of the intaocular measured parameters between males and females (in $\mathrm{mm}$ ).

\begin{tabular}{lcccccc}
\hline & \multicolumn{2}{c}{ Male } & \multicolumn{4}{c}{ Female } \\
& Right side & Left side & $\mathrm{p}$ & Right side & Left side & $\mathrm{p}$ \\
\hline HMP & $9.40 \pm 1.37$ & $9.48 \pm 1.46$ & 0.12 & $9.27 \pm 1.82$ & $9.31 \pm 1.73$ & 0.37 \\
HM & $7.49 \pm 1.36$ & $7.19 \pm 1.18$ & 0.01 & $7.28 \pm 1.96$ & $7.02 \pm 1.60$ & 0.12 \\
HL & $7.73 \pm 1.53$ & $7.96 \pm 1.79$ & 0.11 & $7.61 \pm 1.94$ & $7.73 \pm 1.91$ & 0.26 \\
DLMC & $27.04 \pm 1.64$ & $27.12 \pm 1.84$ & 0.18 & $27.06 \pm 1.85$ & $27.14 \pm 1.46$ & 0.39 \\
Height-length ratio & $35.55 \pm 5.18$ & $35.37 \pm 4.92$ & 0.67 & $33.69 \pm 4.78$ & $33.64 \pm 4.60$ & 0.68 \\
\hline
\end{tabular}

HMP - distance between upper and the lower eyelid margin in the mid-pupillary plane; HM -distance between upper and the lower eyelid margin tangential to the medial of iris' edge; HL - distance between upper and the lower eyelid margin tangential to the lateral of iris' edge; DLMC - distance between medial and lateral canthi.

\section{DISCUSSION}

Dimensions of the palpebral fissure, interpupillary distance, distance between both lateral and medial cathi are important measurements in the evaluation of several syndromes and facial abnormalities and in the surgical treatment. Also, this region of the face shows variations according to age, sex, ethnicity and race. In the present study the morphometric parameters of the palpebral fissure and canthal distances of the Serbian young adult ethnic population were evalueted (Table I - III) and the data was compared with other racial and ethnic groups (Table IV and V).

Table IV. Comparison of distance between both lateral canthi (AngL), distance between both medial canthi (AngM) and interpupillary distance (I) measurements of various populations (in $\mathrm{mm}$ ).

\begin{tabular}{|c|c|c|c|c|c|c|c|c|c|}
\hline \multirow{2}{*}{ Authors } & \multirow{2}{*}{ Year } & \multirow{2}{*}{ Number } & \multirow{2}{*}{ Population } & \multicolumn{2}{|c|}{ DLC } & \multicolumn{2}{|c|}{ DMC } & \multicolumn{2}{|c|}{ IPD } \\
\hline & & & & Male & Female & Male & Female & Male & Female \\
\hline Farkas et al. & 2005 & $\begin{array}{l}\text { Male-30, } \\
\text { Female-30 }\end{array}$ & Egypt & 89 & 86.3 & 31.8 & 30.9 & - & - \\
\hline Farkas et al. & 2005 & $\begin{array}{l}\text { Male-30, } \\
\text { Female-30 }\end{array}$ & Japan & 103.9 & 93.3 & 38.85 & 35.72 & - & - \\
\hline Preechawai & 2011 & $\begin{array}{l}\text { Male-51, } \\
\text { Female-50 }\end{array}$ & Thailand & 88.1 & 85.8 & 30.9 & 32.6 & 61.3 & 59.5 \\
\hline Vasanthakumar et al. & 2013 & $\begin{array}{l}\text { Male-100, } \\
\text { Female-100 }\end{array}$ & South India & 95.55 & 92.44 & 34.27 & 33.41 & 66.72 & 62.59 \\
\hline Present study & 2020 & $\begin{array}{l}\text { Male-45, } \\
\text { Female-45 }\end{array}$ & Serbia & 85.10 & 84.76 & 31.28 & 31.14 & 60.28 & 60.77 \\
\hline
\end{tabular}

DLC - distance between lateral canthi; DMC - distance between both medial canthi; IPD - interpupillary distance.

Table V. Comparation of the palpebral fissure parameters of various population (in $\mathrm{mm}$ ).

\begin{tabular}{|c|c|c|c|c|c|c|c|}
\hline \multirow{2}{*}{ Authors } & \multirow{2}{*}{ Year } & \multirow{2}{*}{ Number } & \multirow{2}{*}{ Population } & \multicolumn{2}{|c|}{ HMP } & \multicolumn{2}{|c|}{ DLMC } \\
\hline & & & & Male & Female & Male & Female \\
\hline Barretto \& Mathog & 1999 & $\begin{array}{l}\text { Male-34, } \\
\text { Female-33 }\end{array}$ & Bleck & $9.84 \pm 1.61$ & $10.56 \pm 1.58$ & $32.34 \pm 2.31$ & $31.46 \pm 2.20$ \\
\hline Barretto \& Mathog & 1999 & $\begin{array}{l}\text { Male-31, } \\
\text { Female-28 }\end{array}$ & White & $10.25 \pm 1.21$ & $10.65 \pm 1.21$ & $29.51 \pm 2.19$ & $29.40 \pm 2.46$ \\
\hline Husein et al. & 2010 & Female-102 & Indian American & - & $9.20 \pm 1.90$ & - & $30.60 \pm 2.40$ \\
\hline Husein et al. & 2010 & Female-200 & American White & - & $10.90 \pm 1.20$ & - & $30.70 \pm 1.20$ \\
\hline Vasanthakumar et al. & 2013 & $\begin{array}{l}\text { Male-100, } \\
\text { Female-100 }\end{array}$ & South India & $11.30 \pm 1.66$ & $11.58 \pm 1.65$ & $31.08 \pm 1.79$ & $29.90 \pm 2.18$ \\
\hline Yu et al. & 2019 & $\begin{array}{l}\text { Male-85, } \\
\text { Female-65 }\end{array}$ & China & $8.4 \pm 1.6$ & $9.7 \pm 1.5$ & $23.9 \pm 2.1$ & $29.1 \pm 2.5$ \\
\hline Yu et al. & 2019 & $\begin{array}{l}\text { Male-40, } \\
\text { Female-30 }\end{array}$ & Indian in Singapour & $10.0 \pm 1.6$ & $11.2 \pm 1.1$ & $23.2 \pm 1.7$ & $27.4 \pm 3.3$ \\
\hline Present study & 2020 & $\begin{array}{l}\text { Male-45, } \\
\text { Female-45 }\end{array}$ & Serbia & $9.43 \pm 1.41$ & $9.14 \pm 1.59$ & $27.19 \pm 1.75$ & $26.90 \pm 1.54$ \\
\hline
\end{tabular}

HMP - distance between upper and the lower eyelid margin in the mid-pupillary plane; DLMC - distance between medial and lateral canthi. 
Sexual differences develop around puberty due to increased testosterone concentration in males (Verdonck et al., 1999), where testosterone is responsible for the development of male secondary sex traits including muscle mass, facial hair, bone and soft tissue growth (Folstad \& Karter, 1992). Weston et al. (2007) found that the growth trajectories of males and females diverge at puberty for bizygomatic width leading to a width-to-height facial dimorphism (greater ratio in males than in females). in the Serbian young adults and in other ethnic groups the mean value of lateral canthal distance for males was higher than those for female (Table IV). Also, medial canthal distance with a significant sex difference was observed on average. Studies conducted in Egypt, Japan, India and Serbia reported greater values of intercanthal distance in males than in females however, studies in Thailand reported slightly lower values in male than in females.

The correlation between race or ethnicity and the palpebral fissure caracteristics has been a subject of interest for decades in anthropology, plastic surgery and forensic medicine. Gifford (1928) has morphologically analyzed the palpebral fissure on images of an Asian population. He described the so-called Asian eyelid as an illusion created by the epicanthal fold and asymmetric narrowing of the fissure. However, he did not perform morphometric analysis in his study. Later, many authors analyzed the palpebral fissure with different methodology in various populations and pointed to morphometric differences (Table V). Its cause probably lies in its genetic, geographical and environmental factors. Studies in India reported greater distances between the upper and the lower eyelid margin in the mid-pupillary plane, while lower values were reported in studies in America and Serbia. The Population in South India shows the widest palpebral fissure, while the population in China the narrowest.

The variation in results from the different studies may be due to non-uniform methodology and techniques. The morphometric evidence of palpebral fissure has been collected by direct measuring techniques (rulers and calipers) or indirect measuring techniques (photography and its computer analysis). Some authors suggest the use of photography and computer analysis in anatomical or anthropological morphometry. This method is simple, standardized, documentable and can be applied in research (Coombes et al., 2007).

Although the two sides of the human body tend to be symmetrical due to biological factors inherent to the processes of development as well as environmental disturbances, perfect bilateral symmetry is rarely found (Lindauer, 1998). Facial asymmetry which includes asymmetry of the palpebral fissure does not necessarily represent an abnormality (Kowner, 1996). Fluctuating asymmetry is also a known variation described by random devations from perfect symmetry in bilateral paried traits and is often believed to reflect development stability, health and attractiveness (Simmons et al., 2004). In a study of male facial anthropometry, Soler et al. (2012) describe that attractiveness was associated with slightly asymmetric faces, but more recent studies of real faces or computer manipulated facial images have often found that facial symmetry is positively correlated with attractiveness. The causes of asymmetry can be traumatic or congenital such as cleft palates, however in the absence of pathology the causes of asymmetry are found in lateralization of the brain. Geshwind quotes the importance of neural crest migration (Geschwind \& Galaburda, 1985). This process terminates simultaneously on both sides of human face, but subtle difference in migration commencement timing is likely to lead to an eventually obvious dominance on the right-side of the face. In the present study some differences were found in the measured parameters in relation to the side of the body of the subjects however, this difference was not statistically significant (Table II and Table III).

\section{CONCLUSION}

In this study, we measured values for various parameters of canthal distance and palpebral fissure in a population of Serbian young adults. The canthal distance measured was not statistically significant between the sexes. In this study it was confirmed that the greater canthal distance was present in males. Also, morphometric parameters of palpebral fissure do not show statistically. The distance between the upper and the lower eyelid margin tangential to the medial margin of iris edge in males was statistically significant $(\mathrm{p}=0.01)$. Other morphometric parameters of the palpebral fissure did not show statistically significant results. When the data of the present study was compared with other studies, the measured paramethers showed differencies based on sex, race and ethnicity.

KNEZI, N.; ISARETOVIC, V.; ADJIC, I.; BABIC, N.; MARIC, D. \& STOJSIC-DZUNJA, L. Análisis morfométrico de la fisura palpebral y la distancia cantal en adultos jóvenes serbios. Int. $J$. Morphol., 38 (5):1381-1385, 2020.

RESUMEN: El músculo orbicular de los ojos se encuentra en la cara, delante de la órbita y debajo de la piel. Los párpados limitan la fisura palpebral, la abertura natural, sujeta a variaciones geográficas, raciales y de edad. Los párpados y la fisura palpebral juegan un papel importante en la estética de las personas, pero 
también en el diagnóstico de ciertos procesos patológicos locales y sistémicos. El objetivo del estudio fue realizar un análisis morfométrico de la fisura palpebral en una población joven sin enfermedades o condiciones patológicas. El estudio se realizó en 90 sujetos (45 hombres y 45 mujeres) de 19,28 \pm 0,69 años. Los sujetos fueron fotografiados con una cámara Nikon D3400, y los parámetros morfométricos se midieron con el software ImageJ $1.48 \mathrm{v}$. El análisis estadístico de los datos se realizó en Windows Excel. Se midieron la distancia entre los puntos medios de ambas pupilas, la distancia entre ambos cantos laterales, la distancia entre ambos cantos mediales, el ancho de la fisura palpebral y la altura de la fisura palpebral en tres puntos. La altura promedio de la fisura palpebral a la derecha fue $9,35 \pm 1,55 \mathrm{~mm}$ y a la izquierda fue $9,41 \pm 1,56 \mathrm{~mm}$. El ancho promedio de la fisura palpebral a la derecha era 27,05 $\pm 1,71 \mathrm{~mm}$ y a la izquierda era 27,18 $\pm 1,68 \mathrm{~mm}$. Se determinó una diferencia leve en los parámetros medidos, sin embargo, esta diferencia no fue estadísticamente significativa.

PALABRAS CLAVE: Morfometría; Fisura palpebral; Distancia cantal.

\section{REFERENCES}

Barretto, R. L. \& Mathog, R. H. Orbital measurement in black and white populations. Laryngoscope, 109(7 Pt. 1):1051-4, 1999.

Coombes, A. G.; Sethi, C. S.; Kirkpatrick, W. N.; Waterhouse, N.; Kelly, M. H. \& Joshi, N. A standardized digital photography system with computerized eyelid measurement analysis. Plast. Reconstr. Surg., 120(3):647-56, 2007.

Farkas, G. L.; Katic, M. J.; Forrest, C. R.; Alt, K. W.; Bagic, I.; Baltadjiev, G.; Cunha, E.; Cvicelová, M.; Davies, S.; Erasmus, I.; et al. International anthropometric study of facial morphology in various ethnic groups/races. J. Craniofac. Surg., 16(4):615-46, 2005.

Folstad, I. \& Karter, A. J. Parasites, bright males, and immunocompetence handicap. Am. Nat., 139(3):603-22, 1992.

Geschwind, N. \& Galaburda, A. M. Cerebral lateralization. Biological mechanisms, associations, and pathology: I. A hypothesis and a program for research. Arch. Neurol., 42(5):128-59, 1985.

Gifford, H. The "Mongolian eye". Am. J. Ophthalmol., 11(11):887-93, 1928.

Hall, J.; Allanson, J. E.; Gripp, K. \& Slavotinek A. Handbook of Normal Physical Measurements. Oxford, Oxford University Press, 2007.

Husein, O. F.; Sepehr, A.; Garg, R.; Sina-Khadiv. M.; Gattu, S.; Waltzman, J.; Wu, E. C.; Shieh, M.; Heitmann, G. M. \& Galle, S. E. Anthropometric and aesthetic analysis of the Indian American woman's face. J. Plast. Reconstr. Aesthet. Surg., 63(11):1825-31, 2010.

Jaja, B. N. R., Fawehinmi, H. B. \& Jack, J. T. Craniofacial anthropometry in a young Nigerian population: the canthal distances. Int. J. Morphol., 29(3):914-7, 2011.

Kowner, R. Facial asymmetry and attractiveness judgment in developmental perspective. J. Exp. Psychol. Hum. Percept. Perform., 22(3):662-75, 1996.

Lindauer, S. J. Asymmetries: diagnosis and treatment. Semin. Orthod., 4(3):133, 1998

Miot, H. A.; Parr dos Santos Fernandes, L.; Jorge, E. N.; Pivotto, D. R.; Nogueira, C. R. \& Ferreira da Silva Mazeto, G. M. Comparative evaluation of oculometric variables in Graves' ophthalmopathy. Clinics (São Paulo), 64(9):885-9, 2009.

Preechawai, P. Anthropometry of eyelid and orbit in four southern Thailand ethnic groups. J. Med. Assoc. Thai., 94(2):193-9, 2011.
Simmons, L. W.; Rhodes, G.; Peters, M. \& Koehler, N. Are human preferences for facial symmetry focused on signals of developmental instability? Behav. Ecol., 15(5):864-71, 2004.

Soler, C.; Kekäläinen, J.; Núñez, M.; Sancho, M.; Núñez, J.; Yaber, I. \& Gutiérrez, R. Male facial anthropometry and attractiveness. Perception, 41(10):1234-45, 2012.

Song, W. C.; Kim, S. J.; Kim, S. H.; Hu, K. S.; Kim, H. J. \& Koh, K. S. Asymmetry of the palpebral fissure and upper eyelid crease in Koreans. J. Plast. Reconstr. Aesthet. Surg., 60(3):251-5, 2007.

Standring, S. Gray's Anatomy. The Anatomical Basis of Clinical Practice. $41^{\text {st }}$ ed. New York, Elsevier, 2016.

Vasanthakumar, P.; Kumar, P. \& Rao, K. G. M. Photogrammetric analysis of palpebral fissure dimensions and its position in Malaysian South Indian ethnic adults by gender. N. Am. J. Med. Sci., 4(10):458-62, 2012.

Vasanthakumar, P.; Kumar, P. \& Rao, M. Anthropometric analysis of palpebral fissure dimensions and its position in South Indian ethnic adults. Oman Med. J., 28(1):26-32, 2013.

Verdonck, A.; Gaethofs, M.; Carels. C. \& de Zegher, F. Effect of lowdose testosterone treatment on craniofacial growth in boys with delayed puberty. Eur. J. Orthod., 21(2):137-43, 1999.

Vezel, F. G.; Clark, R. A. \& Demer, J. L. Facial asymmetry in superior oblique muscle palsy and pilley heterotopy. J. AAPOS, 4(4):233-9, 2000.

Weston, E. M.; Friday, A. E. \& Liò, P. Biometric evidence that sexual selection has shaped the hominin face. PloS One, 8(2):e710, 2007.

Yu, P.; Nathan, P. \& Meng, C. S. Periocular anthropometry of normal Chinese and Indian populations in Singapore. JOJ Ophthalmol., 7(5):555722, 2019.

\author{
Corresponding author: \\ Knezi Nikola MD \\ Teaching Assistant, PhD student \\ University of Novi Sad \\ Faculty of Medicine \\ Department of Anatomy \\ Hajduk Veljka 3 \\ Novi Sad 21000 \\ SERBIA
}

Email: nikola.knezi@mf.uns.ac.rs

Received: 26-04-2020

Accepted: 09-06-2020 